\title{
USE OF ENDOPHYTIC DIAZOTROPHIC BACTERIA AS A VECTOR TO EXPRESS THE cry3A GENE FROM BACILLUS THURINGIENSIS
}

\author{
Joana Falcão Salles ${ }^{1}$; Patrícia de Medeiros Gitahy²; Leif Skøt ${ }^{3}$ José Ivo Baldani ${ }^{*}$ \\ ${ }^{1}$ Plant Research International, Binnenhaven, Wageningen, Holland. 2Embrapa Agrobiologia, Seropédica, Rio de Janeiro, \\ Brazil. ${ }^{3}$ ARFC Institute of Grassland and Environmental Research, Plas Gogerddan, Aberystwyth, Wales, UK.
}

Submitted: December 04, 1998; Returned to authors for corrections: January 11, 2000; Approved: September 20, 2000

\begin{abstract}
The goal of this study was to evaluate the potential of endophytic diazotrophic bacteria as a vector to express a cry gene from Bacillus thuringiensis, envisaging the control of pests that attack sugarcane plants. The endophytic nitrogen-fixing bacteria Gluconacetobacter diazotrophicus strain BR11281 and Herbaspirillum seropedicae strain BR11335 were used as models. The cry3A gene was transferred by conjugation using a suicide plasmid and the recombinant strains were selected by their ability to fix nitrogen in semi-solid N-free medium. The presence of the cry gene was detected by Southern-blot using an internal fragment of $1.0 \mathrm{~kb}$ as a probe. The production of $\delta$-endotoxin by the recombinant $H$. seropedicae strain was detected by dot blot while for G. diazotrophicus the Western-blot technique was used. In both cases, a specific antibody raised against the $B$. thuringiensis toxin was applied. The $\delta$-endotoxin production showed by the G. diazotrophicus recombinant strain was dependent on the nitrogen fixing conditions since the cry $3 A$ gene was fused to a nif promoter. In the case of $H$. seropedicae the $\delta$-endotoxin expression was not affected by the promoter $(r h i)$ used. These results suggest that endophytic diazotrophic bacteria can be used as vectors to express entomopathogenic genes envisaging control of sugarcane pests.
\end{abstract}

Key words: Gluconacetobacter diazotrophicus, Herbaspirillum seropedicae, endophytic bacteria, diazotrophic, cry gene

\section{INTRODUCTION}

The development of recombinant DNA technology has allowed production of many biotechnological products envisaging the biological control of insects, and most of them are related to Bacillus thuringiensis. This bacterium is responsible for $98 \%$ of the world biopesticide market and produces crystals with entomopathogenic activity, composed by proteins ( $\delta$-endotoxins) coded by cry genes. Höfte and Whiteley (13) classified different $\delta$-endotoxins according to their amino acids sequence and their target insect. Recently, a new nomenclature based only on the identity of the amino acids of these toxins was proposed (7).

Most of these biotechnological products were obtained through the transfer of a cry gene to other organisms such as plant (1), cyanobacteria (16), bacteria (21) and viruses (15). These strategies have the potential to improve the $B$. thuringiensis efficacy and persistence, eliminating certain undesirable characteristics of the crystals such as its fast degradation when exposed to sunlight, instability in water and the inability to control insects that feed on internal plant tissue (11).

The insertion of the B. thuringiensis genes into plant chromosomes allows the control of insects that have the habit of feeding internally within plant (1). However to enable the cry gene expression in plants, it is necessary to increase its percentage of $\mathrm{G}$ and $\mathrm{C}$ bases (synthetic gene) to values very close to those found in plants (9). Adang et al. (1) evaluated the $\delta$-endotoxin production in transgenic carrot and corn protoplasts containing the native cry3A gene $(64 \% \mathrm{~A}+\mathrm{T})$ or

\footnotetext{
* Corresponding author. Mailing address: Embrapa - Agrobiologia, Antiga Rodovia Rio-São Paulo, Km 47, Caixa Postal 74505, CEP 23851-570, Seropédica, Rio de Janeiro, RJ, Brasil. Fax: (+5521) 682-1230. E-mail: ibaldani@cnpab.embrapa.br
} 
the synthetic version $(55 \% \mathrm{~A}+\mathrm{T})$ and demonstrated that only the latter was transcribed in a stable manner.

The introduction of cry genes into plant-associated bacteria appears to be more worthwhile since its chromosomal integration is much simpler. Moreover, the similarity of $\mathrm{G}+\mathrm{C}$ content between these organisms and $B$. thuringiensis makes unnecessary changes of the value in the inserted gene. The main restriction to release recombinant bacteria into the environment is the dispersal of a foreign gene to another organism and among the components of risk assessment are persistence and genetic stability. In this way, recombinant endophytic bacteria are good candidates for $\delta$-endotoxin production since their low survival in soil decrease the possibility of cry gene transfer to other soil microorganisms. This strategy proved to be an efficient methodology to inoculate corn plants with Clavibacter xyli subsp. cynodontis containing the crylAc gene (14) to control the European corn borer (Ostrinia nubilalis).

This report describes the introduction and expression of the cry $3 A$ gene from $B$. thuringiensis into endophytic diazotrophic bacteria, envisaging the control of coleopteran pests in sugarcane. Among the main endophytic bacteria which colonise roots and aerial tissues of sugar cane are Gluconacetobacter diazotrophicus (6) and Herbaspirillum seropedicae (3). The former has restricted occurrence, being associated mainly with sugar-rich plants, whereas $H$. seropedicae has a wider host range and neither survive well in soil (2). The expression of the cry3A gene in endophytic diazotrophic bacteria opens new perspectives of a biotechnological technique to control internally plant-tissue feeding insects where chemical and other biological control agents are not effective.

\section{MATERIALS AND METHODS}

\section{Strains, plasmids and growth conditions}

Bacterial strains and plasmids are listed in Table 1. Escherichia coli strains were grown in LB medium (18), Gluconacetobacter diazotrophicus strains were culture either in Dygs medium (8), Potato agar (8), LGI-P semi-solid medium (8) or modified LGI medium (5 g..$^{-1}$ glucose; $5 \mathrm{mM}$ sodium glutamate; 4 g. $1^{-1} \quad \mathrm{~K}_{2} \mathrm{HPO}_{4} ; 6 \mathrm{~g} . \mathrm{l}^{-1} \quad \mathrm{KH}_{2} \mathrm{PO}_{4} ; 0.2 \mathrm{~g} . \mathrm{l}^{-1}$ $\mathrm{MgSO}_{4} .7 \mathrm{H}_{2} \mathrm{O} ; \quad 0.02 \mathrm{~g} .1^{-1} \quad \mathrm{CaCl}_{2} \cdot 2 \mathrm{H}_{2} \mathrm{O} ; \quad 0,002 \mathrm{~g} .1^{-1}$

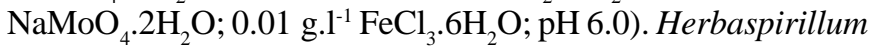
seropedicae strains were grown in JNFB medium (8), Potato agar (8) or modified JNFB medium (JNFB medium containing $5 \mathrm{mM}$ sodium glutamate and without yeast extract and bromotymol blue).

\section{Bacterial mating}

The introduction of the cry $3 A$ gene into the recipient strains BR11281 and BR11335 was achieved by conjugation using as donors E. coli strains containing the plasmids pPBS70 and pPBS80 respectively. The plasmid pRK2013 was used as a helper. The mating was performed onto the surface of filter $(0.45 \mu \mathrm{m}$.) using a ratio of recipient to donor to helper of 10:1:1.

Table 1: Strains and plasmids used in this work.

\begin{tabular}{|c|c|c|}
\hline Bacterial strain & Relevant characters & References \\
\hline \multicolumn{3}{|l|}{ E. coli } \\
\hline JM105 & Plasmid mobiliser strain & 18 \\
\hline HB101 & Plasmid mobiliser strain & 18 \\
\hline \multicolumn{3}{|l|}{ G. diazotrophicus } \\
\hline BR11281 & ATCC 4937; $\mathrm{Nal}^{\mathrm{r}}$ & 6 \\
\hline JS5701 & BR11281::Tn5:nifHp-cry3A; $\mathrm{Km}^{\mathrm{r}}$ & This work \\
\hline \multicolumn{3}{|l|}{ H. seropedicae } \\
\hline BR11335 & $\mathrm{Nal}^{\mathrm{r}}$ & 3 \\
\hline PG5801 & BR11335::Tn5:rhiAp-cry3A; $\mathrm{Km}^{\mathrm{r}}$ & This work \\
\hline \multicolumn{3}{|l|}{ Plasmids } \\
\hline pRK2013 & Helper plasmid & 10 \\
\hline pPBS22 & pKK233-2 containing $\operatorname{trc}$ - $\operatorname{cry} 3 A ; \mathrm{Km}^{\mathrm{r}}$ & Skøt, L. pers. com. \\
\hline pPBS24 & pUC 18 containing cry $3 A$ gene; Amp $^{r}$ & Skøt, L. pers. com. \\
\hline pPBS70 & pSUP1021 containing nifHp-cry $3 A$ fusion with $\mathrm{Tn} 5, \mathrm{Km}^{\mathrm{r}}$ & 20 \\
\hline pPBS80 & pSUP1021 containing rhiAp-cry $3 A$ fusion with Tn5; Km & 20 \\
\hline
\end{tabular}

Ampr:100 $\mu \mathrm{g} \mathrm{ml}^{-1} ; \mathrm{Km}^{\mathrm{r}}: 50 \mu \mathrm{g} \mathrm{ml}^{-1}$; $\mathrm{Nal}^{\mathrm{r}}: 10 \mu \mathrm{g} \mathrm{ml}^{-1}$. 
The filters were placed on Dygs (G. diazotrophicus) or JNFB (H. seropedicae) medium and incubated overnight at $30^{\circ} \mathrm{C}$. The mixture of cells was diluted up to $10^{-3}$ and plated on Dygs or JNFB medium containing nalidixic acid and kanamycin for selection of the recombinants. The colonies obtained were again transferred to the specific medium containing the antibiotics and also plated on Potato agar medium containing $10 \%$ sucrose $(G$. diazotrophicus) and Potato agar $(H$. seropedicae). The recombinants were then inoculated into semi-solid medium and the nitrogenase activity was determined by the acetylene reduction assay (20) to confirm their ability to fix nitrogen.

\section{Extraction of DNA}

Recombinant plasmids from E. coli were obtained by the alkaline lysis method (4). Genomic DNA from recombinant and type strains of both diazotrophics was extracted by the CTAB (cetylmethylammonium bromide) method. The cells were grown in $100 \mathrm{ml}$ of specific medium, centrifuged and resuspended in $2 \mathrm{ml} 10 \mathrm{mM}$ Tris $\mathrm{HCl} \mathrm{pH} 8.0$ containing $1 \mathrm{mM}$ EDTA. Then were added $0.5 \mathrm{ml} 10 \%$ SDS and $10 \mu \mathrm{l}$ pronase (100 mg. ml ${ }^{-1}$ ) and the mixture was incubated at $37^{\circ} \mathrm{C}$ for 1 hour. After the incubation, $1.8 \mathrm{ml} 5 \mathrm{M} \mathrm{NaCl}$ and $1.5 \mathrm{ml} \mathrm{CTAB/}$ $\mathrm{NaCl}(0.7 \mathrm{M} \mathrm{NaCl}$ containing $10 \% \mathrm{CTAB})$ were added and the lysate was incubated for $20 \mathrm{~min}$ at $65^{\circ} \mathrm{C}$. The lysate was extracted with chloroform/isoamyl alcohol (24:1, v/v), phenol/ chloroform/isoamyl alcohol (25:24:1, v/v) and chloroform/ isoamyl alcohol $(24: 1, \mathrm{v} / \mathrm{v})$. The DNA was then precipitated with isopropanol and redissolved in $10 \mathrm{mM}$ Tris $\mathrm{HCl} \mathrm{pH} 8.0$ containing $1 \mathrm{mM}$ EDTA.

\section{Southern blot hybridisation}

A 1,060 bp internal fragment of the cry $3 \mathrm{~A}$ gene, generated by PCR using the primers $\operatorname{col} 2 \mathrm{~A} / \mathrm{col} 2 \mathrm{~B}(5)$, was used as a probe. The purified plasmid pPBS24 containing the whole $c r y 3 A$ gene was added to the PCR mixture $(0.2 \mathrm{mM}$ dNTP, $1.5 \mathrm{U}$ of $\mathrm{Taq}$ DNA-polimerase [GIBCO BRL], 0.1 to $0.5 \mu \mathrm{M}$ of each primer and 10x buffer). The amplification was performed in a thermal cycler (PTC-100, MJ Research, Inc.) by using a program consisting of the following steps: 1 cycle $94^{\circ} \mathrm{C}$ for $1 \mathrm{~min}, 50^{\circ} \mathrm{C}$ for $1 \mathrm{~min}$ and extension at $72^{\circ} \mathrm{C}$ for $1 \mathrm{~min}$. This cycle was repeated 30 times. The PCR product of the correct size was labelled with digoxigenin according to the manufacturer recommendation (DIG DNA Labelling Kit, Boehringer Mannheim Biochemical).

Genomic DNA and plasmids were digested with PstI (Promega) and HindIII (Pharmacia Biotech) restriction enzymes, separated by electrophoresis in a $0.8 \%$ agarose gel and transferred by capillarity to a positively charged nylon membrane (Boehringer Mannheim Biochemical). Hybridisation was performed overnight at $65^{\circ} \mathrm{C}$ and subsequent washings and detection were accomplished according to the manufacturer recommendation (DIG DNA Labelling Kit, Boehringer Mannheim Biochemical).

\section{5. $\delta$-endotoxin production}

Recombinant bacteria grown in flasks containing $900 \mathrm{ml}$ of modified LGI or JNFB medium during a period of 4 days were collected, ressuspended in an extraction buffer $(50 \mathrm{mM}$ Tris $\mathrm{HCl} \mathrm{pH} 8.0$ containing $25 \%$ sucrose, $1 \mathrm{mM}$ PMSF and 60 $\mathrm{mg} \cdot \mathrm{ml}^{-1}$ lisozyme) and disrupted by 10 cycles of freezing/ thawing. The pellet was washed with $5 \mathrm{M} \mathrm{NaCl}$, incubated in an extraction buffer for $30 \mathrm{~min}$ at $4^{\circ} \mathrm{C}$ and washed with $5 \mathrm{M}$ $\mathrm{NaCl}$. The $\delta$-endotoxin was solubilized in $5 \mathrm{mM} \mathrm{Na}_{2} \mathrm{CO}_{3}$ buffer $\mathrm{pH} 10.5$ containing $1 \mathrm{mM}$ DTT for 4 hours at $37^{\circ} \mathrm{C}$, and quantified using the Bradford method (22).

\section{Immunoblot analysis}

Total cellular proteins isolated from G. diazotrophicus, $H$. seropedicae and E. coli strains were separated by SDSpolyacrilamide (10\%) gel electrophoresis, electroblotted onto nitrocellulose filters and probed with primary antibody raised against the solubilised crystal protein isolated from Bacillus thuringiensis subsp. tenebrionis and secondary antibody coupled to Alkaline Phosphatase (Sigma). The $\delta$-endotoxin was visualised by using NBT (nitro-blue-tetrazolium-chloride) e BCIP (5-bromo-4-cloro-3-indoylil phosphate, toluidine salt), according the manufacturer instructions (Bio-Rad).

\section{RESULTS AND DISCUSSION}

The cry3A gene from $B$. thuringiensis was transferred to G. diazotrophicus strain BR11281 and H. seropedicae strain



Figure 1: Detection of the cry3A gene in recombinant strains by Southern blot, using an internal fragment as a probe. The DNA was digested with EcoRI and HindIII restriction endonucleases. Lane 1, pPBS24; lane 2, pPBS70; lane3, BR11281; lane 4, JS5701; lane 5, BR11335; lane 6, PG5801. 


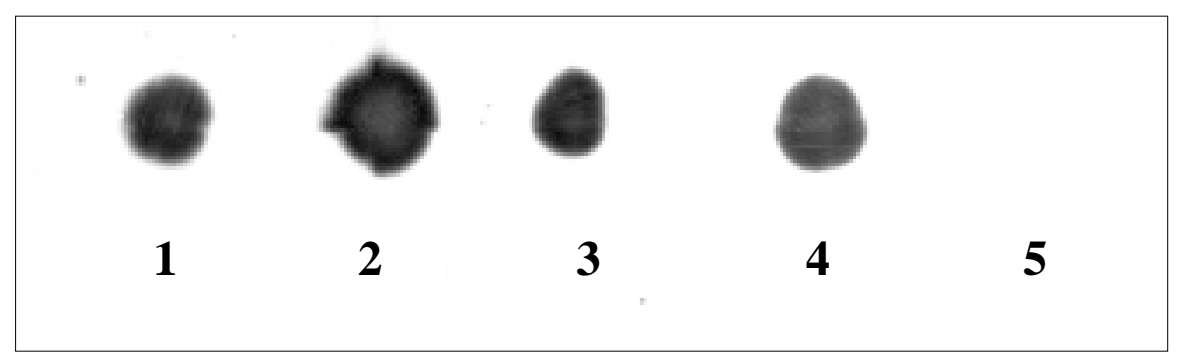

Figure 2: Dot blot analysis showing the presence of the cry3A gene in the recombinant G. diazotrophicus strain isolated from micropropagated sugar cane plants. The genomic DNA was directly applied on positively charged nylon membranes and hybridised with the $c r y 3 A$ probe. Lane 1, pPBS70; lane 2, pPBS22; lane 3, JS5701; lane 4, JS5701 isolated from sugar cane tissue; lane 5, BR11281.

BR11335 by conjugation, using the suicide plasmids pPBS70 and pPBS80 as vectors. In both constructions, the cry $3 A$ gene was hooked in the transposon Tn5. A transposable element instead of a plasmid was chosen as a vector to minimise the likelihood of losing the foreign gene. Skøt et al. (21) observed that transposons rather than plasmids improved the stability of the cry $3 A$ gene in the host genome, therefore decreasing its transference to other organisms.

To avoid selection of recombinant bacteria without the ability to fix nitrogen, all kanamycin resistant colonies obtained were checked. In the case of $H$. seropedicae, all $\mathrm{km}^{\mathrm{r}}$ colonies retained their ability to fix nitrogen in semi-solid JNFB medium (data not shown). In contrast, this ability was lost in many of the G. diazotrophicus $\mathrm{km}^{\mathrm{r}}$ colonies as well as the chocolate colour of the colonies when grown on Potato-P medium (data not shown). Two recombinant strains, one from $G$. diazotrophicus JS5701 containing the Tn5::nifHp-cry3A and one from H. seropedicae PG5801 containing the Tn5::rhiApcry $3 A$, were used in this work. The presence of $c r y 3 A$ gene in JS5701 and PG5801 recombinant strains was confirmed by positive hybridisation signals at 3.0-kb size with the total DNA from both recombinant bacteria (Fig. 1). No signals were observed with total DNA from the original strain. The HindIII/

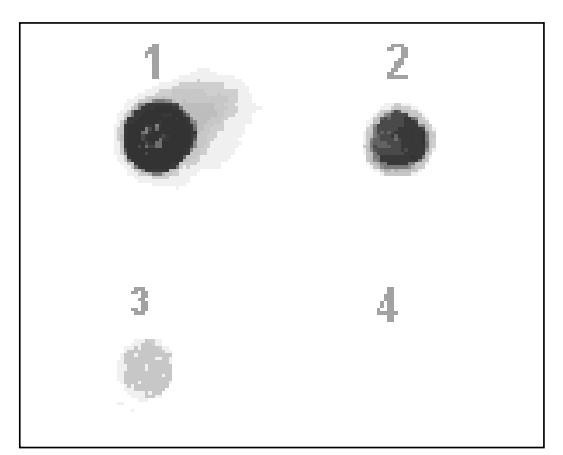

Figure 3: Dot blot analysis showing the $\delta$-endotoxin production by the $H$. seropedicae recombinant strain. The Cry3A was detected using a specific antibody raised against the toxin. Lane 1, HB101(pPBS22); lane 2, HB101(pPBS22); lane 3, PG5801; lane 4, BR11335. The amount of total cellular proteins were not determined.
PstI fragment length ( $3 \mathrm{~kb})$ is consistent with the cry $3 A$ putative sequence described by Sekar et al. (19).

The stability of the cry $3 A$ gene in the recombinant strain JS5701 was confirmed after reisolation of these inoculated strains from micropropagated sugarcane tissues maintained for 10 days in modified MS medium (17). All isolated colonies from $G$ diazotrophicus were kanamycin resistant, indicating that the recombinants retained the inserted gene. This result was further confirmed by a Dot blot hybridisation of the genomic DNA from the reisolated strains with the $c r y 3 A$ probe (Fig. 2).

The $\delta$-endotoxin production by the $H$. seropedicae recombinant strain was confirmed by Dot blot of total cellular proteins with the antibody raised against the Cry3A toxin (Fig. 3). In this recombinant strain, the production of the $\delta$ endotoxin is regulated by a rhi promoter, which seems to be activated when the bacteria are colonising the plant rhizosphere.

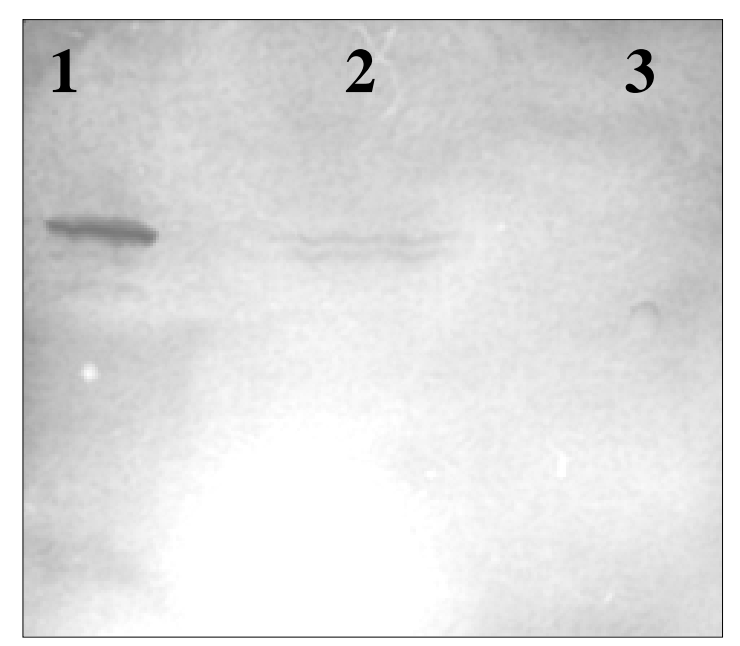

Figure 4: Western blot analysis of the total cellular proteins from $\mathrm{G}$. diazotrophicus showing the presence of a $65 \mathrm{kDa}$ band, which gave positive signal against the antibody specific to $\delta$-endotoxin. Lane 1 , JM105(pPBS22); lane 2, JS5701; lane 3, BR11281. The amount of total cellular proteins applied in each lane was 25,25 and $20 \mathrm{mg}$ of protein, respectively. 
Although the cry $3 A$ gene expression could be detected when the $H$. seropedicae recombinant strain was growing in culture medium, the $\delta$-endotoxin production was higher when root exudates were added (data not shown). These results are in accordance with those obtained by Skøt et al. (21) who showed that even in the absence of root exudates, the Rhizobium leguminosarum recombinant strain, containing the cry $3 A$ gene under the control of the same promoter, was able to produce low amounts of $\delta$-endotoxin. A possible explanation for the activation of the promoter $r h i$ when the recombinant strain was grown in culture medium is the presence of growth factors or co-factors with functions related to those substances released by the root exudates.

The cry $3 A$ gene expression was observed for the $G$. diazotrophicus recombinant strain. A Western blot analysis of the total cellular proteins from $G$. diazotrophicus showed the presence of a $65 \mathrm{kDa}$ band which gave positive signal against the antibody specific to $\delta$-endotoxin (Fig. 4). Because the cry $3 A$ gene is fused to a nif promoter in $G$. diazotrophicus, the $\delta$ endotoxin production was evaluated under nitrogen fixing conditions. The results showed that the nitrogenase activity of both the wild-type and recombinant strain increased during the first two days, reaching its maximum activity at the $3^{\text {rd }}$ day and then decreased to a value similar to that found at the beginning of the experiment (Fig. 5a). The $\delta$-endotoxin production of the recombinant strain increased daily and reached its maximum amount at the $4^{\text {th }}$ day (Fig. 5b). Considering that the cry $3 A$ expression in $G$. diazotrophicus recombinant strain was regulated by the nif promoter it would be expected no $\delta$-endotoxin production when the bacteria were

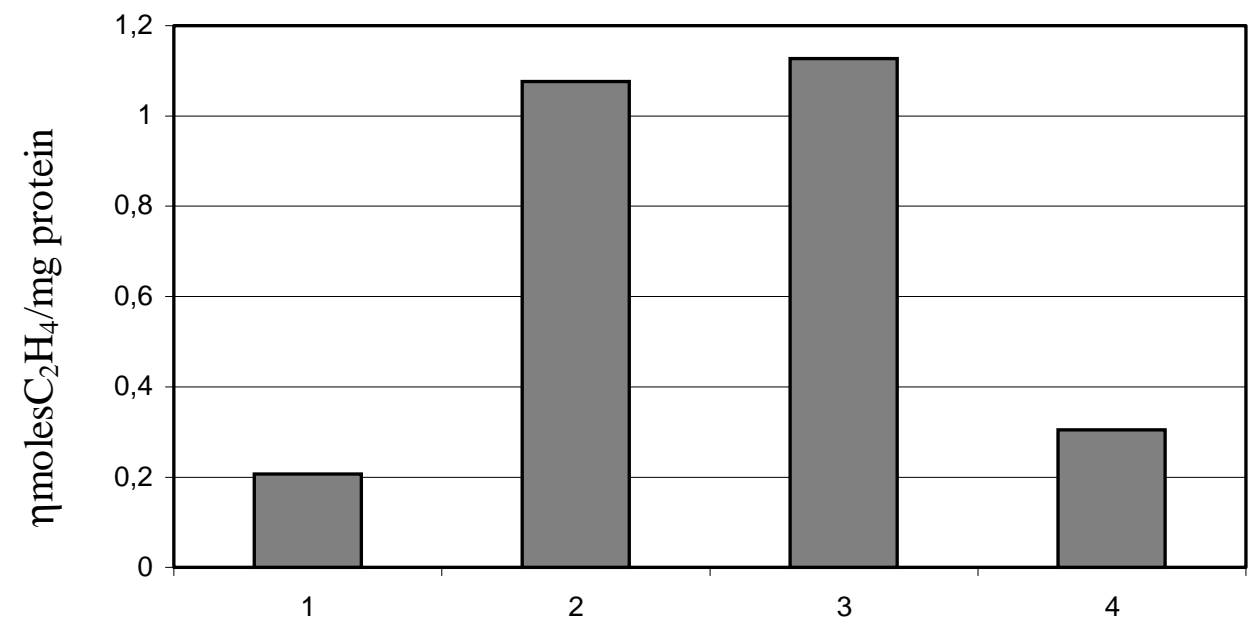

A

Days

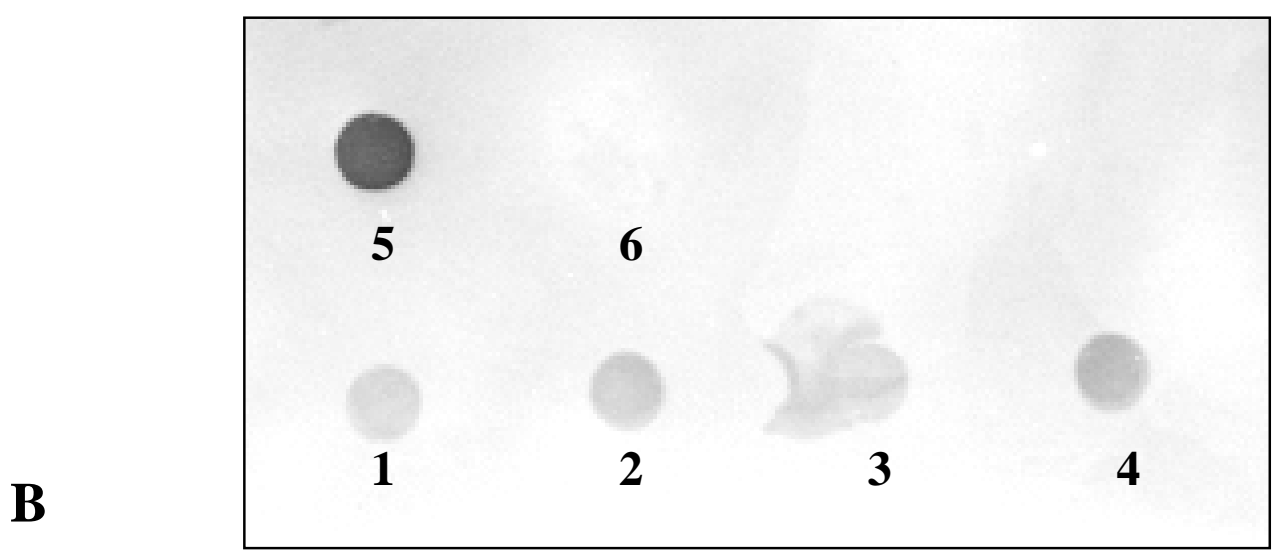

Figure 5: Evaluation of $\delta$-endotoxin production in the $G$. diazotrophicus recombinant strain under nitrogen fixing conditions. A) Nitrogenase activity detected by acetylene reduction assay. B) Dot blot analysis showing the different amount of $\delta$-endotoxin produced by the recombinant strain during a 4-day period. $1,2,3$ and 4) $\delta$-endotoxin production by JS5701 at the $1^{\text {st }}, 2^{\text {nd }}, 3^{\text {rd }}$ and $4^{\text {th }}$ day of growth, respectively; 5) JM105(pPBS22); 6) BR11281. The amount of total cellular proteins applied was 20mg, except for sample 5 (10mg of total cellular protein). 
grown in medium containing an inorganic nitrogen source. The difference between the peaks of nitrogenase activity and the $\delta$-endotoxin production during the experiment could be explained by the high stability of $c r y 3 A$ RNA messenger. In $B$. thuringiensis the half-life of the $\delta$-endotoxin mRNA has an average of 10 minutes (12) and some cis-elements that act as mRNA stabilisers, located at both 3' and 5' end, are responsible for the high stability of $\delta$-endotoxin transcript.

According to Wong and Chang (24), the cis-element that acts at the 3' extremity of the cry mRNA is composed of inverted repeated sequences. The transcription of which leads to the formation of a stem-and-loop structure that protects the mRNA from exonucleolytic degradation, increasing the half-lives of their transcripts and therefore enhancing gene expression (24). Udayasuriyan et al. (23) evaluated the crylAa expression in $E$. coli recombinants and observed that the absence of the structure was responsible for low $\delta$-endotoxin production, probably due to the lower stability of the mRNA. The stemand-loop structure was also detected at the 3' extremity of cry $3 \mathrm{~A}$ gene (19) and this region is present in the cry $3 A$ fragment used in the construction of pPBS70, which may explain the stability of cry3A mRNA in the G. diazotrophicus recombinant strain.

Our results confirmed the introduction of the cry $3 A$ gene and its expression in G. diazotrophicus and H. seropedicae, two diazotrophic bacteria known to colonise endophytically sugarcane. Although the promoters used in the plasmids pPBS70 and pPBS80 were not from $G$. diazotrophicus and $H$. seropedicae species, they were able to direct the cry $3 \mathrm{~A}$ transcription. In plasmids pPBS70 and pPBS80, the cry $3 A$ gene is regulated by the promoter of the operon nifHDK of Rhizobium leguminosarum biovar trifolii and by the promoter of the rhiABC operon in Rhizobium leguminosarum biovar viciae, respectively (21). The use of promoters dependent on regulatory gene-products may avoid the problem of insect resistance caused by the constant production of the $\delta$-endotoxin, because they are activated only under specific conditions. Skøt et al. (21) introduced and expressed the cry $3 \mathrm{~A}$ gene in Rhizobium leguminosarum biovar trifolii strains under the control of the nifHDK operon. The recombinant bacteria were used to control Sitona spp., a coleopteran larvae that feeds on nitrogen fixing root nodules of several legume plants. The expression of the $\delta$ endotoxin was dependent on the age of the nodules. Mature nodules expressed the gene while young nodules were unable to produce the toxin. The use of its own nif promoters would enhance the $\delta$-endotoxin production of $G$. diazotrophicus and $H$. seropedicae species, therefore increasing the efficiency of the recombinant strains. The ability of these bacteria to colonise endophytically the plant tissues associated with their poor survival in soil are characteristics that make these recombinants good candidates to be used as vectors for the control of coleopteran and lepidopteran pests in sugarcane.

\section{ACKNOWLEDGMENTS}

This work was financed by fellowship and bench fees from the Conselho Nacional de Pesquisa (CNPq), Coordenação de Aperfeiçoamento de Pessoal Superior (CAPES) and by Embrapa, project $n^{\circ} 03094$ 122-01.

\section{RESUMO}

\section{Uso de bactérias diazotróficas endofíticas como vetores para expressar cry3A de Bacillus thuringiensis}

Este estudo teve como objetivo avaliar o potencial de uso de bactérias diazotróficas endofíticas como vetores para a expressão de genes cry de Bacillus thuringiensis. As bactérias diazotróficas endofíticas Gluconacetobacter diazotrophicus estirpe BR11281 e Herbaspirillum seropedicae estirpe BR11335 foram usadas como modelo. O gene cry3A foi transferido através de um plasmídeo suicída por conjugação e os recombinantes foram selecionados pela sua capacidade de fixar nitrogênio em meio semi-sólido sem $\mathrm{N}$. A presença do gene cry $3 A$ no genoma dos transconjugantes foi detectada através da técnica de "Southern blot" utilizando como sonda um fragmento de $1,0 \mathrm{~kb}$, interno ao gene cry $3 \mathrm{~A}$. A produção de $\delta$-endotoxina pelos transconjugantes foi detectada por "Dot blot" em de H. seropedicae e por "Western blot" em $G$. diazotrophicus, usando-se o anticorpo específico para a toxina de $B$. thuringiensis. A avaliação da produção da $\delta$-endotoxina mostrou que a expressão do gene cry $3 A \mathrm{em}$ G. diazotrophicus é dependente do processo de fixação de nitrogênio por estar fusionado a um promotor nif nesta bactéria. No caso de $H$. seropedicae a expressão não foi influenciada pelo promotor de rizosfera (rhi) usado. Os resultados obtidos sugerem que estas bactérias diazotróficas endofíticas podem ser usadas como vetores para expressar genes com atividade entomopatogênica, visando o controle de pragas de cana-de-açúcar ou outras plantas de interesse econômico.

Palavras-chave: Gluconacetobacter diazotrophicus, Herbaspirillum seropedicae, bactérias endofíticas, diazotróficas, gene $c r y$.

\section{REFERENCES}

1. Adang, M.J.; Brody, M.S.; Cardineau, G.; Eagan, N.; Roush, R.T.; Shewmaker, C.K.; Jones, A.; Oakes, J.V.; McBride, K.E. The reconstruction and expression of a Bacillus thuringiensis cryIIIA gene in protoplasts and potato plants. Plant Mol. Biol., 21:1131-1145, 1993.

2. Baldani, J.I.; Caruso, L.; Baldani, V.L.D.; Goi, S.R.; Döbereiner, J. Recent advances in BNF with non-legume plants. Soil Biol. Bioch., 29:911-922, 1997.

3. Baldani, J.I.; Baldani, V.L.D.; Seldin, L. and Döbereiner, J. Characterisation of Herbaspirillum seropedicae gen. nov., sp. nov., a root-associated nitrogenfixing bacterium. Intern. J. Syst. Bact., 36:86-93, 1986. 
4. Birboin, H.C.; Doly, J.C. A rapid alkaline extraction procedure for screening recombinant plasmid DNA. Nucl. Ac. Res., 7:1513-1523, 1979.

5. Carozzi, N.B.; Kramer, V.C.; Warren, G.W.; Evola, S.; Koziel, M.G. Prediction of insecticidal activity of Bacillus thuringiensis strains by polymerase chain reaction product profiles. Appl. Environ. Microb., 57:3057-3061, 1991.

6. Cavalcante, V.A.; Döbereiner, J. A new acid-tolerant nitrogen-fixing bacterium associated with sugarcane. Plant and Soil, 108:23-31, 1988.

7. Crickmore, N.; Zeigler, D.R.; Feitelson, J.; Schnepf, E.; Van Rie, J.; Lereclus, D.; Baum, J.; Dean, D. Revision of the nomenclature for the Bacillus thuringiensis pesticidal crystal proteins. Microbiol. Mol. Biol. Rev., 62:807813, 1998.

8. Doberëiner, J.; Baldani, V.D.; Baldani, J.I. Como isolar e identificar Bactérias fixadoras de nitrogênio em não leguminosas. EMBRAPA-CNPAB, Itaguaí, $1995,60 \mathrm{p}$.

9. Fujimoto, H.; Itoh, K.; Yamamoto, M.; Kyozuka, J.; Shimamoto, K. Insect resistant rice generated by introduction of a modified d-endotoxin gene of Bacillus thuringiensis. Bio/Technology, 11:1151-1155, 1993.

10. Figurski, D.H.; Helinski, D.R. Replication of an origin-containing derivate of plasmid RK2 dependent on a plasmid function provided in trans. Proc. Nat. Acad. Sci. USA, 73:1648-1652, 1979.

11. Gelernter, W.; Schwab, G.E. Transgenic bacteria, viruses, algae and other microorganisms as Bacillus thuringiensis toxin delivery systems. In: Entwistle, P.F.; Cory, J.S.; Bailey, M.J.; Higgs, S. (eds). Bacillus thuringiensis, an environmental biopesticide: theory and practice. John Wiley, Chichester, 1993, p.89-104.

12. Glatron, M.F.; Rapoport, G. Biosynthesis of the parasporal inclusion of Bacillus thuringiensis: half-life of its corresponding messenger RNA. C. R. Acad. Sci. Paris, 269:1338, 1341, 1972.

13. Höfte, H.; Whiteley, H.R. Insecticidal Crystal Proteins of Bacillus thuringiensis. Microb. Rev., 53:242-255, 1989.

14. Lampel, J.S.; Canter, G.L.; Dimock, M.B.; Kelly, J.L.; Anderson, J.J.; Uratani, B.B.; Foulke Jr, J.S.; Turner, J.T. Integrative cloning, expression, and stability of the cryIA $(c)$ gene from Bacillus thuringiensis subsp. kurstaki in a recombinant strain of Clavibacter xyli subsp. cynodontis. Appl. Environ. Microb., 60,:501-508, 1994.
15. Martens, J.W.M.; Honée, G.; Zuidema, D.; Van Lent, J.W.M.; Visser, B.; Vlak, J.M. Insecticidal activity of a bacterial crystal protein expressed by a recombinant Baculovirus in insect cells. Appl. Environ. Microb., 56:27642770, 1990.

16. Murphy, R.C.; Stevens Jr., E. Cloning and expression of the cryIVD gene of Bacillus thuringiensis subsp. israelensis in the cyanobacterium Agmenellum quadruplicatum PR-6 and its resulting larvicidal activity. Appl. Environ. Microb., 58:1650-1655, 1992.

17. Reis, V.M.; Olivares, F.L.; Oliveira, A.L.M.; Reis Jr., F.B.; Baldani, J.I.; Dobereiner, J. Technical approaches to inoculate micropropagated sugar cane plants with A. diazotrophicus. Plant and Soil, 206:205-211, 1999

18. Sambrook, J.; Fritsch, E.H.; Maniatis, T. Molecular cloning, a laboratory manual. Cold Spring Harbor, USA, 1989, v.3.

19. Sekar, V.; Thompson, D.V.; Maroney, M.J.; Bookland, R.G.; Adang, M.J. Molecular cloning and characterisation of the insecticidal crystal protein gene of Bacillus thuringiensis var. tenebrionis. Proc. Nat. Acad. Sci. USA, 84:7036-7040, 1987

20. Salles, J.F. Uso de Gluconacetobacter diazotrophicus como vetor para expressão do gene cry3A de Bacillus thuringiensis, visando o controle de coleópteros na lavoura canavieira. Rio de Janeiro, 1998, 64 p. (Master thesis. UFRRJ)

21. Skøt, L.; Timms, E.; Mytton, L.R. The effect of toxin producing Rhizobium strains, on larvae of Sitonia flavescens feeding on legume roots and nodules. Plant and Soil, 163:141-150, 1994.

22. Stoscheck, C.M. Quantification of protein. In: Deutscher, M.P. (ed.) Methods in enzymology: guide to protein purification. Academic, Califórnia, 1990, p.50-67.

23. Udayasuriyan, V.; Nakamura, A.; Masaki, H.; Uozumi, T. Enhanced expression of cryIA(a) gene of Bacillus thuringiensis in Escherichia coli. J. Fermen. Bioengen., 82:306-308, 1996.

24. Wong, H.C.; Chang, S. Identification of a positive retroregulator that stabilises mRNAs in bacteria. Proc. Nat. Acad. Sci. USA, 83:3233-3237, 1986. 